\title{
L. B. POULSENS ERINDRINGER
}

\author{
VED \\ THADE PETERSEN \\ FRIMENIGHEDSPRAST, HADERSLEV
}

$+$

$\mathrm{V}$

ed de nordslesvigske Frimenigheders Aarsmøde i Bovlund Søndag den 9. Oktober 1910 opfordrede en af Talerne, Gaardejer Mads Gram fra Københoved, de aldre Menighedsmedlemmer til at give deres Erfaringer og Oplevelser videre til Ungdommen. Dette Krav fra hans Side fandt stærk Tilslutning i Forsamlingen og blev støttet af flere andre Talere. I den Sammenhæng opfordrede jeg de xldre i Menighederne til skriftligt eller mundtligt at fortalle deres Minder fra Frimenighedernes Vaartid. Dertil svarede Poulsen, at han ikke kunde skrive om Gennembrudstiden, men han vilde gerne i Frimenighedskredse fortalle om den. Nogen Tid derefter indfriede han dette Løfte ved et Menighedsmøde i Haderslev. I Tilslutning til, hvad han der havde fortalt, bad jeg ham om at nedskrive sine Erindringer. Nej, sagde han, skrive kan jeg ikke. Skal jeg skrive noget, skal det helst være i Form af et Brev. Men kom ud til mig. Saa vil jeg fortælle, og saa kan du skrive. Ikke længe derefter tilbragte jeg omtrent en Uge i hans Hjem, hvor han fortalte, mens jeg noterede saa meget, at jeg her har været i Stand til at gengive Fortallingen som hans, skønt jeg her og der har maattet sætte senere Tilføjelser ind i deres rette Sammenhæng. Kort Tid forinden havde jeg faaet Jac. Kloppenborg fra Harreby og Jørgen Gundesen fra Vimtrup til at fortælle om Frimenighedsbevægelsens Opstaaen og Udfoldelse paa Røddingegnen. Baade det og Poulsens Meddelelser gav mig yderst værdifuldt Stof til min Bog om Frimenighederne. Men jeg fik jo derved en Mængde biografisk Stof, som jeg ikke fik udnyttet i Frimenighedernes Historie. For Jac. Kloppenborgs Vedkommende brugte jeg det til hans Levnedstegning i „Sønderjydske Aarbøger" 1925. Her skal jeg nu fremlægge, hvad Poulsen fortalte om sin Barndom og Ungdom, indtil han i 1867 blev sat fra sin Lærergerning og derved ført ind paa Vejen til den Gerning, han længe vil mindes for, Gerningen som Frimenighedspræst i Bovlund. 


\section{BARNDOM}

Jeg var som Dreng stor af min Alder, men noget tilbage $i$ aandelig Udvikling. De andre Drenge vilde derfor gerne drille mig, og jeg havde ondt ved at værge mig mod dem. Min Fader syntes, jeg var alt for godmodig, og jeg husker godt, hvor glad han var, da han første Gang saa, at jeg kunde slaa fra mig i en Kamp med Snebolde.

Min Fader var Daglejer og arbejdede bl. a. ved Tørvestrygning. Det tog han mig tidligt med ud til. Han havde sin egen Fordeling mellem Mad og Arbejde. Naar vi skulde ud at grave Tørv for en Mand, spiste vi jo vor Morgenmad paa Gaarden. For det meste havde vi derfra langt ud til Mosen. Naar vi saa kom derud, satte vi os ned og spiste al den Mad, vi havde med til hele Dagen. Naar det saa var besørget, rejste Fader sig, idet han sagde: „Saa, nu har vi kun det rene, skære Arbejde tilbage. "Det blev der saa drevet paa med saa lang Dagen var.

I I0-I 2 Aars Alderen kom jeg ud at tjene hos en Mand i Obbekær. Jeg skulde vogte Køer i Engene ned mod den store, mørke Fæsted Mose. Manden, jeg tjente hos var slem til at bande, Karlene ligeledes. Jeg lærte det da ogsaa hurtigt og fik snart saa stor Øvelse i at bruge de Bande, jeg hørte, at jeg kunde sætte dem sammen i ny Forbindelser og slynge saadan en Remse ud over Køerne, naar de ikke ret vilde skikke sig. Til andre Tider kunde der imidlertid dukke op i mig en Følelse af, at jeg var ved at glide ud i noget, jeg ikke kunde forsvare. Naar det f. Eks. tordnede, og jeg befandt mig ene med Køerne derude ved Mosen kunde jeg blive overfaldet af Angst for at blive kaldt til Regnskab for, hvad jeg sagde og gjorde, og saa turde jeg ikke bande. Jeg begyndte $i$ det hele allerede at faa Følelsen af, at jeg skulde være anderledes, end jeg var. Hvordan jeg saa skulde være, forstod jeg naturligvis ikke, men der foresvævede mig nærmest noget i Retning af som Johannes Kloppenborg1 ${ }^{\mathbf{1}}$ var. Ham kendte jeg jo godt nok; og ham saa jeg op til, og jeg tænkte undertiden: „Saadan skulde du egentlig være." Jeg fik dog ikke gjort Alvor af det den Gang og i det hele ikke, saa længe jeg kunde selv.

Mens jeg var i Obbekær gik jeg om Vinteren til Skole i Kamptrup. Læreren der hed Bødtcher. Han var hjærtelig greben af Kristendommen uden dog at høre til de saakaldte vakte, de pietistiske og herrnhutiske Kredse. Han kunde i Religionstimerne tale saadan til os, at det gjorde stærkt Indtryk paa os, selv

1 Gaardejer Johannes Kloppenborg i Harreby, ivrig Pietist. Se „De sønderjydske Frimenigheders Historie“ og „Sønderjydske Aarbøger" 1925 S. 108 ff. 
om det, han talte om, sommetider var uforstaaeligt for os. Jeg havde derfor tit, i den Tid jeg gik til Skole, en daarlig Samvittighed over for ham for de Løjers og Gavtyvestregers Skyld, vi Drenge drev. Særlig galt blev det den Vinter, jeg gik til Konfirmandundervisning i Hygum hos Kapellanen, Hjort, der senere kom til Spandet. Han var ligesom Bødtcher en alvorlig, hjærtegreben Kristen. Han kunde tale med os selv om de vanskeligste Ting - $f$. Eks. Fødselen som en Skaberakt - saadan, at vi blev grebne af det og aldrig glemte det.

Vi Drenge var den Vinter, vi gik til Præsten, kommen slemt i Gang med at spille Kort. Naar vi gik fra Præsten, løb vi lige hen til min Morbroder, Kromanden. Der sad vi saa indtil Middag ved en Høvlebænk i Stalden og spillede Kort. Da min Morbroder opdagede det, jog han os ud af Stalden. Vi fandt saa en Plads paa et Loft. Der var det koldt, blæsende og mørkt, men vi døjede det altsammen blot for at faa et Spil Kort. Senere fandt vi et noget bedre Tilhold hos en gammel Aftægtsmand i Fæsted. Jeg var ivrigt med i Kortspillet, men havde ikke nogen god Samvittighed ved det. Da vi saa en Dag var paa Hjemvejen efter at have spillet Kort, mødte vi Pastor Hjort. Han var til Hest, men holdt Hesten an, da han naaede hen til os. „Saa,“ tænkte jeg, „nu gaar det galt. " Han vilde imidlertid kun spørge, om nogen af os vilde i Købmandslære, da hans Broder, der var Købmand, søgte en Lærling. Glade var vi, at det ikke var vort Kortspil, han havde opdaget og nu vilde tale med os om.

\section{KRISTELIG VÆKKELSE}

Efter min Konfirmation kom jeg til at tjene hos min Morbroder i Hundebøl. Der delte jeg Kammer med en Karl, der hed Hans Peter. Af ham fik jeg det dybeste og varigste Indtryk i kristelig Retning. Han hørte til de saakaldte „fynske" Opvakte. Andre Familier af den Retning var Fredslunds i Hygum, Mads Pedersens i Brendstrup og Knud Hansens i Grønnebæk. De var alle tilflyttet fra Fyn. Men ogsaa nogle der fra Egnen sluttede sig til dem f. Eks. Bendix i Stenderup, der var Gaardejer, men ved Siden af drev lidt Handel med gudelige Bøger, og Hans Skrædder, der boede Syd for Brendstrup.

Hans Peter var en dygtig, tro og stilfærdig Karl. Han gjorde aldrig noget Forsøg paa at prædike for os andre eller $i$ det hele at paavirke os $i$ kristelig Retning, men naar vi om Aftenen var gaaet til Sengs, kunde jeg ikke undgaa at mærke, at han stille bad sin Aftenbøn. Jeg tænkte da undertiden: „Det skulde du egentlig ogsaa gøre." Det blev imidlertid ved Tanken. Til Udførelse kom den ikke den Gang endnu. Men i mit 18. Aar faldt jeg i en svær Sygdom, og 
under den brød det igennem, som allerede længe havde gæret i mig. Jeg blev mig fuldt bevidst, at mit Liv ikke var, som det skulde være, og efter at jeg var kommen til Kræfter igen, sluttede jeg mig til de fynske gudelige Forsamlingers Folk. Hos dem fandt jeg mest af det, jeg trængte til.

$\mathrm{Da}$ der saaledes var vaagnet Trang til rigere $\mathrm{Liv} \mathrm{i}$ mig, varede det ikke længe, inden Trangen til at udrette noget i Guds Rige meldte sig hos mig. Men skulde jeg blive i Stand til det, forstod jeg nok, at jeg maatte skaffe mig langt fyldigere Oplysning, end jeg havde, og i det hele stile imod Opdyrkning af mine Evner. Det første Sted jeg i det Øjemed søgte hen til, var Højskolen i Rødding - dog ikke for at blive Elev der, men for at laane Bøger i Biblioteket. Høgsbro' ${ }^{1}$ hjalp mig godt til rette med det. Under Læsningen blev jeg snart klar over, at jeg trængte til langt mere Undervisning og til Uddannelse til en bestemt Gerning. Jeg besluttede mig da til at søge Optagelse paa et Lærerseminar. At blive Lærer syntes jeg var den eneste Vej, ad hvilken jeg kunde naa frem til en Stilling, $i$ hvilken jeg kunde komme til at udrette lidt i Guds Rige.

Den Vinter boede jeg hjemme hos min Moder og forberedte mig ved Læsning til Optagelsen paa Seminariet. Blandt det, jeg skulde kunne noget af, var ogsaa Violinspil. Men Violinen brugtes jo til at spille paa til Dans. Et Instrument, der brugtes til noget saa syndigt, turde jeg med min unge pietistiske Opfattelse ikke give mig af med. Naar jeg skulde øve paa den, gjorde jeg det derfor paa Bagsiden. Det gjorde jeg ogsaa, endnu efter at jeg var bleven optaget paa Seminariet i Tønder. Det gav jo ikke megen musikalsk Færdighed.

Det Seminar, jeg først tænkte paa at søge til, var det i Jelling. Det vidste jeg nemlig lidt om, fordi en Søn af Provst Matzen i Hygum var Præst der i Byen og Lærer ved Seminariet, og han var af den Slags Præster, som de hellige der hjemme nok kunde bruge. En Lørdag tidlig i Foraaret gik jeg derned. Det var en stærk Østenvind, saa at det blev en baade lang og drøj Tur. Om Søndagen hørte jeg Forstanderen, Pastor Svendsen, prædike. Den Prædiken var ikke ret efter mit Hoved, og da jeg bagefter talte med ham, vilde jeg nok eksaminere ham lidt med Hensyn til hans Kristendomsopfattelse. Det havde han imidlertid ikke Tid til at tale med mig om og henviste mig derfor til Matzen. Heller ikke han passede mig ret. Han var mig alligevel for grundtvigsk - ligesom Svendsen. Jelling syntes mig efter dette at være for farligt et Sted at komme. Jeg gik hjem igen og drog senere til Tønder.

1 Sophus Høgsbro, Forstander for Rødding Højskole $1850-62$. 


\section{PAA SEMINARIET}

Paa Vejen dertil fulgtes jeg med Lycke ${ }^{1}$, hvis Fader var Degn i Hygum og med flere andre der fra Egnen. Vi gjorde Turen til Fods og gik og talte om, hvad vi havde læst. De andre havde alle læst en hel Del, jeg næsten intet. Jeg tænkte derfor: „Det slipper du aldrig godt fra." Jeg var saa daarligt forberedt, at jeg egentlig kun havde læst Allen ${ }^{2}$. Kendskab til Bibelen havde jeg heller ikke stort af. Jeg stolede paa de Oplevelser, jeg havde haft, og som for mig endnu ved den Tid betød mere end alt andet. Alligevel gik det ret godt ved Prøven. Jeg blev optaget som Nr. I 3 af 32 . Hvad der gjorde meget, var vel nok det, at jeg saa trygt kunde lægge det hele i Vor Herres Haand og derfor var rolig og uden Frygt for Udfaldet.

Blandt mine Kammerater paa Seminariet var der ingen, jeg havde kristeligt Fælleskab med. Jeg var derfor til at begynde med ret ensom $i$ aandelig Henseende. Blandt Lærerne var Pastor Dahl den forste, der fangede min Interesse. Jeg hørte ham prædike og følte mig tiltalt af ham som Præst, kom ogsaa snart i Huset hos ham og kunde samtale med ham om det, der laa mig paa Sinde. Han viste mig hen til Lærerne Rosendahl ${ }^{3}$ og Appel ${ }^{4}$. Til at begynde med kunde jeg bedst med Rosendahl. Først senere lærte jeg at sætte Pris paa Appel, og han blev da ubetinget den, der kom til at betyde mest for mig. Han var ved den Tid helt Grundtvigs Discipel og førte ogsaa mig i den Retning. En Del betød det da ogsaa i den Henseende, at Pastor Dahl gennem Søren Kierkegaard var havnet hos Grundtvig, og at Thurah ${ }^{5}$ ligeledes var paavirket af ham. Det sidste Aar, jeg var i Tønder, boede jeg i Appels Hjem og var saaledes under daglig Paavirkning af ham. Der synes for Resten ikke at have været hverken Herrnhuter eller fynske Forsamlingsfolk i Tønder. Havde der været nogen af dem der, vilde Pastor Dahl sikkert have vist mig hen til dem.

Vor Religionslærer Meyer kom jeg ogsaa en Del hos. Han tilhørte ikke nogen bestemt Retning, men gjorde paa mig omtrent samme Indtryk som Pastor Hjort i Hygum. Han blev senere Præst i Ringgive.

Kaptejn Thurah kom jeg ogsaa nogle Gange hos. Han stødte mig dog somme-

1 Død som Frimenighedspræst i Rødding 1924. \& Sandsynligvis hans „Lærebog i Danmarks Historie til Skolebrug". " J.J. Rosendahl, Lxrer ved Borgerskolen i Tønder, afsat af Preusserne i Marts 1864, døde som Larer i Høve paa Sjælland. " Cornelius Appel, Elementarlærer ved en af Borgerskolerne i Tønder og Timelærer i Skrivning ved Seminariet. 1874-89 Frimenighedspræst i Rødding. Laurids de Thurah, Kaptejn, Andenlærer ved Seminariet. 
tider ved sin ringeagtende Omtale af Herrnhuterne. Han var vist nok noget paavirket af Grundtvig.

Undervisningen i Tønder var god. Thurah, der underviste i Historie og Geografi, var især udmærket til at fortælle. Han eksaminerede os kun hvert Fjerdingaar i det gennemgaaede Stof, og det var skriftligt. Imidlertid fik vi for lidt Anvisning paa Bøger, vi kunde bruge. Som Følge deraf maatte vi skrive meget. Men ellers kunde Historieundervisningen vist godt staa Maal med den paa en temmelig god Højskole.

Forstander, Professor Kühnels Undervisning i Bibelhistorie og Bibelforklaring var mere tør.

Meyers Troslære var god. Han var et klart Hoved og gav en jævn og letforstaaelig Fremstilling af Stoffet. Han kunde godt taale Indvendinger mod den og drøfte dem med os. Jeg gjorde ikke saa sjældent saadanne Indvendinger ud fra mit pietistiske Syn paa Kristendommen.

Af de nævnte Lærere var det dog Thurah, der særlig satte Præg paa Seminariet.

Endnu mens jeg opholdt mig paa Seminariet havde jeg et Sammenstød med Forstanderen om hans egen Undervisning i Bibelforklaring. „Nordisk Skoletidende“, der udkom i Odense, havde begyndt en Artikelrække „Paraleller imellem de danske Seminarier" og i Nr. 6, 1862 bragt en Artikel om Seminariet i Skaarup. Efter Opfordring havde jeg skrevet en om det i Tønder, som fremkom i det følgende Nummer. Om Bibelforklaringen skrev jeg med det grundtvigske Syn paa Religionsundervisning, som jeg nu havde tilegnet mig, bl. a.: „Det historiske i det gamle Testamente meddeles saa vidt muligt med Bibelens Ord, dog saaledes, at Eleverne mestendels kan hjælpe sig igennem ved at fortælle efter Müllers Bibelhistorie og forklare efter Kurtzes Vejledning i Bibellæsning. Den Del af det gamle Testamente, der ikke indeholder historisk Stof, som Salmerne, Ordsprogene, Profeterne o. s. v. meddeles der et Slags Indholdsfortegnelse over, væsentlig saaledes som Indholdet er angivet over hvert Kapitel i den almindelige Bibeloversættelse, ligesom der ogsaa anstilles Undersøgelser om vedkommende Bøgers Egthed o. s. v., og der meddeles alt det historiske, man véd om Forfatterne, Bøgernes Affattelsestid og -sted." Om Kirkehistorien skrev jeg, at den var „mere Kætter- end Kirkehistorie“.

Denne min Meddelelse vakte en hel Del Opsigt paa Seminariet, og et Fjerdingaar efter dens Fremkomst gjorde "flere af Seminariets Elever" Indsigelse imod den i samme Blad, idet de hævdede, at det havde været min Hensigt at dadle, at min Fremstilling var ensidig, at jeg havde givet Forstanderen „et vist 
despotisk Anstrøg“, at hans Bibelforklaring havde „ikke blot Navn men ogsaa Karakter af Bibelforklaring, og at det var usandt, at Kirkehistorien var mere Kætter- end Kirkehistorie“. Til Slutning bemærkede de at „den Paastand, at vore 3 fastansatte Lærere væsentlig giver Seminariet Karakter ikke er rigtig; ti en af Timelærerne bidrager desværre sit dertil saavel i som udenfor Seminariet".

Den sidste Sætning var naturligvis møntet paa Appel og hans Indflydelse i grundtvigsk Retning.

Til alt dette bemærkede Redaktionen, at det maatte være læst mellem Linjerne. I Artiklen stod der intet om det. Den havde $\mathrm{i}$ det hele kun meddelt Kendsgerninger og ikke indladt sig paa Bedømmelse. „Skumlende Hentydninger" agtede Redaktionen ikke at ændse.

Jeg svarede paa Indsigelsen med en udførligere Beretning om Seminariet i Tønder, som fremkom - under Navn - i Nr. 25. Inden jeg skrev den var jeg imidlertid paa Seminariet bleven udpeget som Ophavsmand til den første Beretning, som havde været anonym. Jeg blev derefter kaldt ind til Professor Kühnel og havde en længere Samtale med ham navnlig om Bibelforklaringen og i det hele om Religionsundervisningen. I denne Samtale hævdede jeg mit Syn, mens han naturligvis forsvarede sin Fremgangsmaade. Jeg maatte ganske vist indrømme - hvad jeg da heller ikke havde nægtet - at hans Forklaring var udførligere end Indholdsangivelserne over Kapitlerne, mens han paa sin Side ikke kunde nægte, at den var i Stil med dem, og jeg havde den Tilfredsstillelse, at vi efter den Tid blev fritaget for at lære de enkelte Kapitler og kun behøvede at gengive Indholdet af dem med egne Ord. I det væsentlige havde jeg altsaa faaet Ret.

Jeg havde for Resten en Gang før besværet mig over et Forhold paa Seminariet. Den sidste Jul, jeg var Elev der, besøgte jeg Forstanderen for paa fleres Vegne at bede ham om at blive fri for Omflytningerne ved Eksamen, da vi syntes de var uværdige for os. Denne Besværing tog han godt imod. Vi blev for Fremtiden fri for Omflytningerne.

Fra 28. April til 8. Maj 1862 havde vi Afgangseksamen. Min Optræden i det sidste Fjerdingaar kom mig her slet ikke til Skade. Jeg fik i alle Fag „udmærket godt" eller „meget godt" og som Hovedkarakter "meget dulig“ med 195 Points og blev saaledes Nr. 4 af de 26 , der bestod Eksamen.

I den ovennæunte „udførligere Beretning“, som jeg skrev tæt efter at jeg havde forladt Seminariet, indrømmede jeg, at naar man tog Ordet Bibelforklaring i den almindelige forstandsmæssige Betydning, saa havde vi faaet virkelig og endogsaa god Bibelforklaring, givet dygtigere og med større Inderlighed end 
paa de fleste andre Seminarier, men som „Undervisning, der bidrager til at oplukke Bibelens dybe aandelige Indhold, saa den Aand, der har talt gennem Skriftens Forfattere, ligesom træder frem for Tilhørerne og lader høre sin mægtig og kærlig vækkende, kaldende og oplysende Røst" og fører Eleverne derhen, hvor „Herren har ladet Livskilden springe, for at alle Støvets Børn - _ - kan deri blive fornyede til evigt Liv" havde den ingen Betydning.

Af de Kammerater paa Seminariet, jeg efterhaanden fik mest Omgang med, skal jeg især nævne Lycke, Jacob Kloppenborg ${ }^{1}$, Gustav Johannsen ${ }^{2}$, Chr. P. Jacobsen fra Aabenraa, der fra 1868-8I udgav „Landmandsbladet" og i 1872 var med til at oprette Markfrøkontoret, som han blev Leder af efter at han i 1873 var flyttet til København ${ }^{3}$. M. M. Schmidt fra Bovlund, der senere blev Redaktør af „Bornholms Tidende“, Kjølseth fra Aabenraa, der i mange Aar var Kordegn i Randers og Carstens, der blev Forstander for Bergs Navigationsskole. Gustav Johannsen kom jeg dog i de Aar ikke meget sammen med. Han var et Aar senere end mig.

Den af dem, jeg fik mest med at gøre var Jacob Kloppenborg, skønt han kom Aaret efter mig. Han var fra Harreby i vort Nabosogn. Han var opvokset $i$ et strengt herrnhutisk Hjem. Faderen var meget utilfreds med, at han vilde paa Seminariet. Da jeg var hjemme i Ferien, kom de over til os for at tale med mig. Faderen var ikke meget opbygget af, hvad jeg fortalte fra Seminariet. Han mærkede jo nok, at jeg allerede var smittet af de grundtvigske Tanker, som var ham en Vederstyggelighed, men Sønnen satte sin Vilje igennem, og jeg kørte med dem til Tønder efter Ferien. Undervejs besøgte vi en herrnhutisk Familje i Arrild4. Der var de ogsaa meget utilfreds med mig.

I den Tid, vi var sammen i Tønder omgikkes jeg meget med Jacob Kloppenborg, og jeg hjalp ham med hans Arbejde, især med Regning og Stil. Skønt han var vel begavet, havde han vanskeligt ved at tilegne sig de Kundskaber, der krævedes. Vi spadserede tit sammen, og han havde mange Spørgsmaal at drøfte med mig. Jeg blev ved alt dette en Hjælper for ham til at komme ud af det pietistiske Snæversyn, han var opdraget i. Jeg fik ham ogsaa med til Pastor Dahl og Rosendahl, senere ogsaa til Appel. Det endte med, at han tilsidst helt sluttede sig til det grundtvigske Syn paa Kristendommen ligesom jeg.

I Foraaret 1862 gik jeg som før nævnt op til Eksamen. Kühnel gav mig i Anledning af min Indstilling til Eksamen denne Anbefaling:

1 Gaardmandssøn fra Harreby. Se „Sønderjydske Aarbøger“ 1925. 2 Senere Rigsdagsmand. s Se Biografisk Leksikon VIII Bd. S. 345 f. " Rimeligvis Erik Andersen Bastian, „gamle Jerk", som han kaldtes. Se J. Brodersen: „Fra gamle Dage“ S. $218 \mathrm{ff}$. 
„Laurids Bertelsen Poulsen fra Hundebøl blev optagen som Elev paa det kongelige Skolelærer-Seminarium i Tønder den 29. April 1859. I de tre Aar, i hvilke han har nydt Seminariets Undervisning, har han bestandig arbejdet med Flid, Alvor og tænksom Selvstændighed og derfor ogsaa gjort gode Fremskridt. Jeg holder mig derfor overbevist om, at han vil blive en dygtig og samvittighedsfuld Lærer. Paa Seminariet har hans Opførsel altid været rosværdig.

Efter at have gennemgaaet det fuldstændige Kursus agter han $i$ indeværende Foraar at underkaste sig den befalede Afgangsprøve.

Forstanderskabet for det kongelige Skolelærer-Seminarium i Tønder den 9. Marts 1862.

A. Kühnel."

Eksamenen gik jo for mit Vedkommende rigtig godt. Jeg underkastede mig ogsaa Prøven i Tysk. Det har jeg nu aldrig været synderlig granner til. Det blev da ogsaa kun „temmelig godt“. Ogsaa Gymnastik lod jeg mig prøve i. Det gav da „meget godt".

\section{LÆRER I RANGSTRUP}

Straks efter min Eksamen fik jeg Ansættelse som Andenlærer i Rangstrup. Samtidig kom flere andre unge Lærere her til Egnen, nemlig M. M. Schmidt, Chr. Appel (senere Lærer paa Sjælland), Hammershøy (fra Agerskov) og Rosendal (Farbror til nuværende Frimenighedspræst Knud Rosendal ${ }^{1}$. Den sidstnævnte Lærer kom fra Blaagaard Seminarium. De kom alle med ny Undervisningsmetoder og søgte ogsaa at virke oplivende ved Afholdelsen af Aftenmøder for de voksne. Det satte Liv i Egnens Befolkning, men vor Undervisningsmaade vakte ogsaa Opsigt, og der rejste sig en Del Modstand mod den. Jeg skrev i den Anledning til Grundtvig for at faa Raad og Hjælp, men jeg fik ikke noget Svar. Ogsaa hos andre søgte jeg Styrkelse i min og mine jævnaldrendes Maade at undervise paa. I min første Sommerferie rejste jeg saaledes over til Kold i Dalum og drøftede Forholdet med ham. "Jeg vil,“ sagde han, „raade jer til at faa Folk skilt ad, saa at de, der kan sammen med jer, slutter sig til jer i en fri Skole. " Jeg besøgte ogsaa nuværende Landstingsmand Jørgen Pedersen. Han havde allerede nogen Tid holdt Friskole, men havde kun faa Elever, saa at det ikke kunde fortsættes.

Efter min Hjemkomst fortsatte vi med vore Møder, som vi i Almindelighed holdt i Skolen. Der var imidlertid allerede begyndt et Arbejde med større Møder, ogsaa under aaben Himmel. Det var „Dansk Samfund“, der foranstaltede dem.

1 Død I931 som Sogneprast i Hellested paa Sjælland. 
Medvirkende ved dem var Morten Eskesen ${ }^{1}$ og Sigfred Ley ${ }^{2}$. Som Talere havde de faaet Thurah, Appel, J. L. Knudsen o. a. til at komme. Møderne afholdtes i Mandbjerg Skov og en enkelt Gang paa. „Hyholm“3.

Til Aftenmøderne om Vinteren var der ret god Tilslutning, ogsaa af Folk, der ellers ikke helt delte det grundtvigske Livssyn. Ved dem talte jeg for mit Vedkommende om dansk-nationale Emner for en stor Del historisk. Med visse Mellemrum holdt Pastor Boesen Bibellæsning i Skolen. Saa deltog vi i den. Ved disse Lejligheder talte jeg dog ikke, saa vidt jeg husker.

Pastor Boesen var i 1858 kommen fra Vodder til Agerskov. Han var noget pietistisk i sin Kristendomsopfattelse, men sluttede sig dog til Grundtvig og deltog i de Møder, der holdtes paa Egnen. Hans Børns Huslærer P. L. Juhl begyndte i Efteraaret 1860 at holde Aftenskole for voksne unge i Præstegaarden. Til dette samlede han rigelig en halv Snes unge Mænd. Efter at Juhl var flyttet til Sjælland fortsatte Lærer Juul i Bovlund Aftenskolen. Som Tilsynshavende ved Skolerne i Sognet var Pastor Boesen ked af det, naar Folk kom og klagede over vor Undervisningsmaade. Han selv personlig kunde heller ikke helt samtykke med os $\mathrm{i}$ vor Maade at tage vort Skolearbejde paa og vilde $\mathrm{i}$ hvert Tilfælde gerne have, at vi skulde gaa forsigtigere til Værks ved Indførelsen af det ny. I Hovedsagen var han ellers enig nok med os.

Der var da for Resten ogsaa en Del af selve Befolkningen, der straks forstod Fortrinnet ved den friere Undervisning og ydede os fornøden Støtte. Af dem kan jeg f. Eks. nævne Refslunderne, Appel i Rangstrup og Fausbøl. Efterhaanden naaede da ogsaa flere til at forstaa det rigtige $i$ den.

\section{I KRIG}

Da Krigen brød ud i I 864 følte jeg det som min Pligt at gøre, hvad jeg kunde, ogsaa i den Henseende. Som fast ansat Lærer var jeg ikke forpligtet til Militærtjeneste, men jeg syntes ikke jeg kunde unddrage mig den. Jeg tænkte længe paa det at melde mig som frivillig og talte ogsaa med andre om det. Blandt det der stod i Vejen for at gaa med i Krigen var ogsaa den Gæld jeg havde. Hos min Morbroder havde jeg laant Penge til Uddannelsen, og han forstod ikke, at jeg kunde føle mig forpligtet til at gaa med i Krigen, naar jeg sad i en Stilling, der gav mig Ret til at blive hjemme. Inden jeg kunde melde mig som frivillig, maatte jeg derfor have mine Pengesager ordnet. Jeg gik i det Øjemed

1 Den Gang Lxrer i Hyrup i Bevtoft Sogn. ${ }^{2}$ Huslærer hos Landstingsmand Aug. Bech i Visby. Se Biogr. Leksikon X, S. 263 f. ' En enligt beliggende Pold midt ude i Bovlund Enge. 
til flere af mine Venner og Bekendte og fik dem til at kavtionere for 25 gamle Daler ${ }^{1}$ hver. De forpligtede sig derved til at betale Beløbet, enten jeg faldt eller blev lemlæstet, saa at jeg ikke selv kunde betale. I Rangstrup havde de fleste for Resten ogsaa ondt ved at forstaa, at jeg vilde med i Krigen. Først da de mærkede, at jeg falmede ved at gaa og gruble over det, gik det op for dem, at det var fuldt Alvor for mig. Jeg fik det da ordnet saaledes, at min Morbroder havde fuld Sikkerhed for sine Penge. Da jeg kom med Kavtionsbeviserne, syntes han, det var lidt flovt for ham, men han tog dog imod dem. Ogsaa med Provsten og Amtmanden fik jeg det ordnet saadan, at mit Embede stod aabent for mig, naar jeg kom tilbage.

Efter at jeg saaledes havde faaet mig frigjort, rejste jeg ved Nytaarstide til København og meldte mig som frivillig. Jeg kom til at bo hos Oberstinde Fru Wagner. Hendes Svigersøn, Ludvig Schrøder, der var Forstander for Højskolen i Rødding, havde skrevet til hende om at tage sig af mig. Her kom jeg til at bo sammen med Officersaspirant, Skovrider Christian Schrøder, Broder til Johannes og Ludvig Schrøder.

Paa Vejen til København overnattede jeg paa Højskolen i Dalum hos Kold. Han havde nær taget Modet fra mig. Da han fik at vide, hvad jeg havde i Sinde, sagde han: „Tror De, at De kan udrette noget, der kan give Krigen en anden Vending? “ Nej, det troede jeg da ikke. Ja saa vilde han raade mig til at blive hjemme. Han havde prøvet noget lignende i 1848 . Jeg sagde saa, at det var for min egen Skyld, jeg maatte med. Det havde han ikke noget at sige til. Han vilde nærmest se, om det ikke kun var en Flyvegrille hos mig. Han havde selv syntes, at han havde alle de Egenskaber, der var nødvendige for at blive en god Soldat, da navnlig Fædrelandskærlighed, men han opdagede snart under Øvelserne, at han ikke havde „Fingerfærdighed“ nok. Det gik mig noget lignende. Da jeg efter Dybbøls Fald skulde eksercere sammen med de andre, mens vi laa paa Fyn, blev jeg tit bag efter og maatte have særskilte Øvelser.

Jeg boede i København altsaa hos Fru Wagner. Hun og jeg stødte for Resten undertiden sammen med vore forskellige Meninger om Klosterpolitikken. Iøvrigt traf jeg $\mathrm{i}$ hendes Hjem mange gode Folk, bl. a. Ernst Trier og Ludvig Wagner, som indførte mig hos Grundtvig. Jeg var i København fra lige efter Nytaar til midt i Marts, da jeg kom til Dybbøl. Meste Tiden derovre gik med Øvelser. Min Kaptejn var Svend Grundtvig. Han kendte Bunde Refslund i Bovlund, som havde givet ham Oplysninger om Eventyr og Kæmpeviser. Derved kom ogsaa jeg i Forbindelse med ham. Min Fritid havde jeg jo til egen Raa-

1 à $3 \mathrm{Kr}$. 20 Øre. 
dighed, og den brugte jeg saa godt som muligt saaledes, at jeg kunde faa noget ud af Opholdet derovre.

Mit første Indtryk af Livet i Dybbøl Skanserne fik jeg af Angrebet den 1 7. Marts. Da hørte jeg første Gang Kuglerne hvine og var unægtelig lidt underlig ved det. Vi stod opstillet, klar til Udrykning og ventede, at vi skulde med. Det slap vi imidlertid for. Angrebet blev jo afslaaet.

Jeg havde i København læst sammen med en ung norsk Frivillig, Bogbinder Moe. Vi laa ogsaa nu sammen ved I8. Regiment. Moe og jeg var fælles om forskellige Ting, bl. a. om en Kaffekande. Den brugte vi for Resten baade til Kaffe og til Øllebrød.

Efter denne første Dag var vi stadig med i Skanserne. Der blev jævnlig nogen ramt af Granatstumper, men det vænnede man sig snart til, blev ret inderlig ligegyldig ved det og gik roligt sin Gang uden at bryde sig om Skydningen. Kun en enkelt Dag var jeg noget ængstelig. Jeg lagde da i Bøn mit Liv i Guds Haand og overvandt min Frygt og Uro.

Christian Appel, der senere i mange Aar var Forstander for Holsted Efterskole, var ogsaa med. Han var en dygtig Soldat og blev udnævnt til Korporal. En Dag, jeg havde været nede ved Lazarettet med en Mand, der var bleven ramt i Nakken, men dog nok kunde gaa, traf jeg paa Tilbagevejen Appel. Han havde Tid til at gaa med, og vi fulgtes saa ad op ad Landevejen. Tyskerne skød netop voldsomt den Dag. Vi gik alligevel aabenlyst. Det var i Virkeligheden farligt, men vi var allerede bleven saa vant til det, at vi ikke ændsede Faren.

„Det er varmt, “ siger Appel saa med Hentydning til den voldsomme Skydning. "Ja," siger jeg, „men det bedste $\mathrm{i}$ os kan de da ikke ramme.“

Senere sagde han: „Den Udtalelse har jeg haft godt af. Før tænkte jeg, at de ikke kunde ramme mig, men det var jeg nu kommen til at tvivle paa. Nu har jeg fundet Tryghed $\mathrm{i}$ det, Du sagde."

En Dag var hans Deling noget sløv. Det kunde han ikke lide. Han vilde da have dem til at synge. Men det kunde de ikke, paastod de. „For Skam da“, udbrød han, „kan I da ikke bande? " Jo det kunde de nok. Og det gjorde de den ene efter den anden. Om han saa ogsaa fik dem til at synge, ved jeg ikke, men han fik da Humøret livet op i dem.

Fra hans senere Virksomhed som Friskolelærer mindes jeg i denne Forbindelse et morsomt Træk af hans Maade at tage Eleverne paa. Der blev klaget over, at Drengene havde ødelagt et Plankeværk. Han blev imidlertid saa glad over at se, at de havde faaet saa stort et Stykke Arbejde gjort, at han ikke kunde nænne at skænde paa dem for det. 
En hel Maaned havde jeg været paa Dybbøl og havde endnu ikke faaet Lejlighed til at skyde paa Tyskerne. Men den sidste Dag før Stormen kom vi til at bruge vore Bøsser. Jeg laa ude ved Landevejen. Da var de lige ved Skanserne med deres Løbegrave. Vi kunde lige naa dem og de ogsaa os. Vi skød da efter dem, naar der var nogen at se.

Den I7. April om Aftenen blev vi afløste i Skanserne og kom til Brohovedet. Der stod vi altsaa den 18 . April. Vi hørte den vældige Kanonade, saa vældig som aldrig før. Pludselig hørte den op. Der blev en ængstelig Stilhed. Tyskerne kom nu i Løb op af Løbegravene og tog det hele i Løbet af ganske kort Tid. Da Skanserne saa var taget, begyndte Stormløbet paany ned mod Brohovedet. Vi var dog dækket der, men kunde ingenting gøre. Vi var de sidste, der kom over Broen. Saa laa vi der i Sønderborg og kunde høre, hvor de festede og spillede derovre paa den anden Side.

Faa Dage efter Stormen blev jeg syg af Overanstrengelse og indlagt paa Augustenborg. Senere blev jeg ført til København og indlagt paa Frederiksberg Slot. Der blev jeg en Del af Sommeren.

I den Tid kom jeg en Del hos Sofus Høgsbro. Han var dog sjælden hjemme, da Rigsdagen helt optog ham. Det var derfor hans Kone, jeg fik mest med at gøre. Med hende havde jeg mange Samtaler om kristelige Forhold. Jeg hørte ogsaa tit til, naar hun fortalte Sagn og Historie for Børnene. Der var jeg som hjemme.

Ligeledes kom jeg en Del hos Niels Lindberg eller rettere hos hans Moder og Søster Elise. Der traf jeg sammen med Lorenz Birkedal. Niels Lindberg var jo en meget lærd Mand, men vilde gerne samtale med os, ogsaa i Spøg. Han var meget fornøjelig.

Det tredje Sted, jeg kom, var hos gamle Grundtvig. Det var nu rigtignok det mindst hjemlige af de tre Steder. Alligevel kunde jeg godt samtale med ham. Dog kom jeg ikke den Gang synderligt i med ham. Det skete først, efter at jeg havde talt ved Vennemødet i $1869 \mathrm{og}$ vi havde faaet Grundtvig knyttet til vor Sag her i Nordslesvig. Han sad under min Tale og godtede sig og lo ${ }^{1}$. „Det var en Karl!" sagde han, da jeg kom ned af Talerstolen. Det gjorde jo mig godt.

I Juli kom jeg tilbage til mit Regiment paa Fyn og hjem i Avgust efter at Fredspræliminærerne var underskrevne.

Skønt min Deltagelse i Krigen ikke varede ret længe, havde den dog været haard og anstrengende nok, og et nedslaaende Indtryk havde den jo gjort paa mig. Alligevel var det mig en Tilfredsstillelse, at jeg havde været med og saaledes ikke havde svigtet, hvad der lød i mit Indre. Desuden oplevede jeg jo

1 Poulsen talte som altid senere sønderjydsk Folkemaal. 
derved det, at det at være Kristen kunde bære en oppe selv der, hvor Død og Lemlæstelse truede en. Paa en enkelt Dag nær gik jeg rolig i det alt sammen. Selv den I8. April kunde jeg staa rolig og tryg, mens det suste med Granater og Stumper og Kugler rundt om en. Det at have været tro mod sig selv, og det at have følt, at man kunde gaa trygt under Faren, vilde jeg ikke have undværet. Det har derfor alligevel haft noget at betyde for mig selv, skønt det ikke fik det for Landet.

Da jeg vendte hjem, stod mit Embede i Rangstrup jo aabent for mig. Efter at Tyskerne havde taget Styret, maatte jeg prøves i Tysk af Provst Blædel. Det var dog ikke stort jeg kunde. For Resten kunde jeg uhindret undervise paa samme Maade som før. Men i 1867 kom saa Edsspørgsmaalet. Den almindelige Opfattelse var, at man ved at aflægge Eden blev tysk, forpligtede sig til at blive det. Derfor rejste der sig saa stærk Modstand mod Edsaflæggelsen. Den Opfattelse havde jeg ikke. En Ed skal efter min Mening forstaaes saadan, at den, der modtager den, skal ligesaagodt holde sig Loven efterrettelig som den, der aflægger den, og man har godt nok Lov til at arbejde paa en Æ̇ndring af Tilstanden og Loven. Jeg havde derfor ingen Skrupler ved at aflægge Eden, men det havde alle mine Slægtninge. Naar jeg alligevel nægtede at aflægge Eden, saa var det, fordi jeg nok kunde forstaa, at vilde jeg vedblive at være fri og frank og arbejde imod Tyskerne, saa vilde jeg alligevel blive smidt væk som Lærer. Jeg havde derfor ingen Grund til at gøre noget, som i alle mine og min Hustrus nære Slægtninges $\emptyset_{j n e}$ saa mistænkeligt ud. Jeg kunde altsaa lige saa godt sige Nej straks.

Vi havde for Resten drøftet Spørgsmaalet ikke saa lidt. Meningerne var delte, men Eksistensspørgsmaalet fik afgørende Indflydelse paa mange, saa at de aflagde Eden og blev i deres Embede. Provst Blædel var oprindelig stemt for at nægte Edsaflæggelsen, da vi havde en Forhandling om det hos Pastor Randbøl i Bevtoft, men inden det kom til Stykket, svingede han og raadede til at aflægge Eden. Han begrundede, saa vidt jeg husker, dette med, at det vilde være heldigst for Befolkningen. Det vilde det ogsaa have været, hvis man ikke derved var bleven svækket i sit eget Liv, som mange faktisk blev det, da Tyskerne begyndte at bruge Magt. Claus Lycke, Fog i Vodder og jeg var oppe hos Overpræsident Scheel-Plessen for at bede om at blive fri for at blive edfæstet, men fik selvfølgelig Afslag. Jeg nægtede altsaa at aflæge Eden og fik saa i Maj I867 min Afsked. Jeg havde holdt Bryllup den I7. August I866. Nu maatte vi saa forlade vort Hjem efter faa Maaneders Forløb. 